Cook, I, Ward, S and Ward, K

A springtime journey to the Soviet Union: Post-war planning and policy mobilities through the iron curtain

Cook, I, Ward, S and Ward, K (2014) A springtime journey to the Soviet Union: Post-war planning and policy mobilities through the iron curtain. International Journal of Urban and Regional Research, 38 (3). pp. 805-822.

This version is available: https://radar.brookes.ac.uk/radar/items/7416bb33-8525-415e-903a-c242f9003abf/1/

Available on RADAR: October 2016

Copyright $(C$ and Moral Rights are retained by the author(s) and/ or other copyright owners. A copy can be downloaded for personal non-commercial research or study, without prior permission or charge. This item cannot be reproduced or quoted extensively from without first obtaining permission in writing from the copyright holder(s). The content must not be changed in any way or sold commercially in any format or medium without the formal permission of the copyright holders.

This document is the post print version of the journal article. Some differences between the published version and this version may remain and you are advised to consult the published version if you wish to cite from it. 


\section{A SPRINGTIME JOURNEY TO THE SOVIET UNION: POST-WAR PLANNING AND POLICY MOBILITIES THROUGH THE IRON}

CURTAIN

Ian R. Cook (ian.cook@northumbria.ac.uk), Department of Social Sciences and Languages Northumbria University, Lipman Building, Sandyford Road, Newcastle upon Tyne, UK, NE1 $8 \mathrm{ST}$

Stephen V. Ward (vward@brookes.ac.uk), Department of Planning, Oxford Brookes University, Headington Campus, Gipsy Lane, Oxford, UK, OX3 0BP

Kevin Ward (kevin.ward@manchester.ac.uk), Geography, School of Environment and Development, University of Manchester, Oxford Road, Manchester, UK, M13 9PL

\section{Acknowledgements:}

We would like to thank Oliver Moss, Matthew Gandy and the three anonymous reviewers for their comments on earlier versions of the paper. Thanks to the Leverhulme Trust and Oxford Brookes University for financially supporting the research behind the paper and thanks finally to all the archivists and librarians at various institutions who provided assistance when we were conducting the research. 


\begin{abstract}
This paper builds upon a relatively small but growing literature in geography, planning and cognate disciplines that seek to understand the variegated geographies and histories of policy mobilities. The paper uses a case study of an exchange trip between town planners in the Soviet Union and the UK during 1957-58. It focuses on the experiences of the British planners in the Soviet Union and sets the tour in the wider context of a fluctuating and sometimes turbulent history of Anglo-Soviet politics, travels and connections. In doing this, the paper makes three arguments. First, that there is much to be gained by bringing together the geography-dominated policy mobilities literature with that on the exchanges and visits by architects, engineers and planners. Second, that the greater sensitivity to the histories of policy mobilities allows contemporary studies to be contextualized in the longer history of organized learning between different urban professions. Third, that despite the long history to policy mobilities what differentiates the current era from previous eras is the prominent 'knowledge intermediary' roles now played by consultancies and think tanks. As the paper will demonstrate, it was branches of government and professional bodies, rather consultancies and think tanks, that have tended to dominate such roles previously.
\end{abstract}




\section{Introduction}

On the evening of 14 May 1958 a Tu104 plane from Prague landed at Vnukovo airport in Moscow. Six British planners stepped onto the tarmac to be welcomed by an ensemble of government officials. They were also met by two interpreters who would accompany them on a 22 day tour of the Soviet Union. For one member of the British delegation, Richard Edmonds (the Chair of London County Council's Town Planning Committee), they were greeted like friends and partners in learning:

"Passports are yielded up at the plane door and in a moment or two we are in the arms of friends, friends I say in part because of their smiling warm-hearted welcome, but through the memory, too, of a busy week in London in September [1957]... when, together we looked at the new London risen from the blitz, told of our difficulties, and pointed to what we felt were our successes. Now here we were at the start of the return visit" (Edmonds, 1958: 10)

Both the 1957 Soviet trip to the UK and this return visit to the Soviet Union were wellpublicized events. Numerous reports of both appeared in local and national newspapers in the UK and in the Soviet Union. The Kentish Mercury (1958: 5), for instance, announced that Edmonds was due to go "behind the curtain" to explore the intricacies of Soviet planning. Edmonds and the leader of the trip, Frederic J. Osborn, both wrote reports in The Evening News (London) and The Daily Telegraph and Morning Post respectively (Edmonds, 1958a, 1958b, 1958c; Osborn, 1958a). Detailed reports and commentaries by almost all members of the party also appeared in the Journal of the Town Planning Institute, Town and 
Country Planning, the Town Planning Review and The Chartered Surveyor following their arrival back in the UK (Osborn, 1958b; Town and Country Planning, 1958a, 1958b; Town Planning Review, 1958; Wright, 1958; Riley, 1959; Wells, 1959). Edmonds, furthermore, had his entertaining diary of this "not-to-be-forgotten adventure" published, entitled Russian vistas: a springtime journey to Moscow, Leningrad, Kiev, Stalingrad, the Black Sea and the Caucasus (Edmonds, 1958d: 7). All these accounts related what had been seen and done, who had been met, and what had been learnt to readers in the UK largely unaware of life and town planning in the Soviet Union.

Rather than being just a quaint episode from a bygone era, over 50 years later the tour poses questions of the burgeoning academic literatures on policy mobilities which focus on the contemporary circulation and mutation of expertise, ideas, models and policies between places (see, for instance, Cook and K. Ward, 2011, 2012a, 2012b; González, 2011; McCann, 2008, 2011; McCann and K. Ward, 2010, 2011, 2012a, 2012b; Peck, 2011; Peck and Theodore, 2001, 2010a, 2010b; Prince, 2010, 2012). In these accounts, most of the principal circulation nodes are situated in Western Europe and North America, with the US and UK frequently 'host' and 'donor' countries (e.g. Cook, 2008; Dolowitz et al., 1999; Jones and Newburn, 2007; Peck and Theodore, 2001; K. Ward, 2006). As Dolowitz et al. (1999) note, policy circulations often occur between places with similar political infrastructures or ideologies. Indeed, the neoliberal ideology - crudely captured as stimulating/“freeing' markets and creating appropriately 'entrepreneurial' and 'flexible' individuals - is seen to underpin many of the contemporary en vogue policies currently circulating. For Peck and Theodore (2001; Peck, 2002), the movement of policy is both a symptom of the rise of neoliberalism (especially the demand for 'fast' policy development) and a crusader or lubricant for neo-liberal 'colonization'. Even where the empirical focus has moved away from the global north to include examples of north-south, south-north and south-south movements, 
neo-liberalism is still represented as an important factor (Bunnell and Maringanti 2010; Peck and Theodore 2010b). We do not doubt the current importance of neo-liberalism, but we do caution against equating policy mobilities - past, present and future - exclusively with the neo-liberal 'moment', as is often implied. Importantly, recent work gives us few clues as to how to understand the circulation of expertise, ideas, models and policies 'outside' the neoliberal frame, particularly those that pre-date both the ascendance of neo-liberalism in the making of policy and its emergence as an object of sustained academic inquiry. This is the challenge to which we turn in this paper, as we seek to highlight the historical precedents to the current mobility of policies. Thus, we ask what can we make of the 1958 trip to the Soviet Union by the six British planners? What were the institutional pre-conditions in both countries that made this trip possible? How did it fit with, or react against, the existing cultural, economic, political and social structure? What did they actually do on the visit? How did they make sense of what they experienced? Were there barriers to movement and understanding? What were the implications of the trip?

With these questions in mind, this paper starts to explore the relatively under-explored (as least to those outside of urban history and planning) policy mobilities beyond the neoliberal frame, focusing on those between the Soviet Union and the UK. The paper is structured as follows. The next section examines the current ways in which cities are understood relationally, focusing specifically on the work that has emerged on urban policy mobilities. We then consider the evolution of post-1917 planning policy networks between the Soviet Union and the UK. Using published reports and archival materials written in English such as letters, lecture notes and itineraries produced by those people hosting, attending or facilitating the 1958 tour of the Soviet Union, we focus on the second leg of the exchange, explore in-depth the rationale and experiences of the tour, and its implications for post-war planning in the UK. In so doing, we will make three arguments. First, that there is 
a longer history to the circulation of expertise and ideas, models and policies that is sometimes implied in the current work on urban policy mobilities. While neo-liberalism may have altered the intensity, as well as the form of the models circulating, the technologies used and the pathways constructed in the present day, the circulation of urban policies, models and expertise is certainly not a new phenomenon nor is it an exclusively neo-liberal one. Second, that the greater sensitivity to the histories of policy mobilities allows contemporary studies to be contextualized in the longer history of organized learning between different urban professions. Third, that despite the long history to policy mobilities what sets the current era apart from the post-war era is the prominent 'knowledge intermediary' roles now played by consultancies and think tanks. As this study shows, it was branches of government and professional bodies, rather than consultancies and think tanks, which dominated such roles during the post-war era.

\section{Relational cities and mobile policies}

The intellectual project of "thinking space relationally", led by the likes of Allen et al. (1998), Amin (2004) Massey (2004, 2007) and others is, according to Jacobs (2012: 142), the “mantra of early $21^{\text {st }}$-century geography." This 'relational turn' has had widespread consequences for all of us working in the field of urban studies as this has led to the boundaries of 'the field' being rethought.

As part of the relational turn there have been a series of interventions into how we should think comparatively about cities in the context of the empirical and conceptual challenges of the twenty first century (McFarlane 2010; Robinson, 2011; K. Ward, 2010). An important element to this renewed interest in comparison amongst urban scholars has 
been a focus on the everyday, mundane and ordinary ways in which comparison is put to work by those who govern and plan cities - what Robinson (2004) and Clarke (2012) term as 'actually existing comparative urbanisms'. Central to this still-emerging body of work is the studies on policy mobilities. Focusing on an increasingly wide array of policy arenas, from creativity (Peck, 2011) to economic development (Cook and K. Ward, 2012b), sustainability (Temenos and McCann, 2012) to welfare (Peck and Theodore, 2001, 2010b), these studies have explored "how and why certain ideas become mobile and what channels are used to diffuse them" (González, 2010: 1403). In particular, the work on policy mobilities has analysed the actors and institutions involved in constructing, circulating and re-embedding policy models, including recent work on consultants (Prince, 2010, 2012) and academics (Jacobs and Lees, 2013). It has also examined the technologies and sites of learning and comparison involved in creating and circulating policy models such as study tours, conferences and best practice guides, what McCann (2011) terms 'informational infrastructures' (Cook and K. Ward, 2011, 2012a; González, 2011; K. Ward, 2011). Emphasis is placed on the process of translation - in other words, how policies are made mobile, making them seem appropriate and transferrable, and the processes through which policies are re-made as they move across space (McCann and Ward, 2012a, 2012b; Peck and Theodore, 2010a).

As both Jacobs (2012) and Harris and Moore (2013) have rightly argued, the geography-dominated policy mobilities literature shares important commonalities with the literatures in urban, planning and architectural history particularly those on the transnationalization of planning and architecture (e.g. Almandoz 1999; Banerjee 2009; Friedman, 2012; Healey and Upton, 2010; Harris and Moore, 2012; King, 1980; Sanyal 1990; Stead et al., 2010; S.V. Ward, 2010a, 2012). This work is deeply rooted, drawing on earlier writings by Sutcliffe (1981), Meller (1995), Saunier (2001) and others. On the whole, the major 
strengths of the work have been empirical, detailing the travels of particular architects and planners, firms, blueprints, models and ideas. Especially pertinent to present concerns, there have been occasional studies, principally by architectural historians, on interchanges of architectural and planning personnel, knowledge and practice between the West and the Soviet Union (e.g. Cooke, 1977, 1978; Kopp, 1990; Glendinning, 2009; Flierl, 2011).

In common with the policy mobilities literature, this work - largely by planners and architects - addresses the ways in which "ideas get re-shaped as they 'travel', losing some dimensions and accumulating others... and what happens when they arrive in particular places" (Healey 2010: 10-11). Particular attention here has been paid to the longer histories of circulating planning ideas and actors, their positions within wider processes of colonialism and post-colonialism, and the power relations that shape these circulations (e.g. King, 1980; Banerjee, 2009; S.V. Ward, 2010a; Friedman, 2012). Yet these studies do not simply demonstrate flows from Western cities to elsewhere, or from colonial powers to their colonies and ex-colonies (important as they are). Friedman's (2012) study of the Indian influences on the design of the new town Reston, Virginia, for instances, troubles such assumptions over 'one-way traffic' from the 'model' cities in Western Europe and North America to the 'imitators' cities in the rest of the world. Unsettling this further, a recent special issue of The Journal of Architecture explores the movement of architectural and planning ideas and expertise from the Soviet bloc more generally to the developing world (Stanek and Avermaete, 2012).

This paper will advance existing work in three ways. First, and echoing Phelps and Tewdwr-Jones' (2008) earlier call for greater positive dialogue between geographers and planners, we argue that research on urban policy tourism and mobile policies requires further trans-disciplinary conversations between geography, planning, history and other cognate disciplines. Conceptually this might alert those working on current forms of policy mobilities 
to the historical continuities in the process as well as the differences, countering the presentdayism that is detectable in some work. Second, through its focus on policy tourism in the 1950s the paper provides an insight in the ways in which policy tourism is shaped by its 'internal' components but also by the wider context in which it occurs. It is a product of particular times, places and social relations. This is not to say that policy tourism does not involve commonalities, as recent studies have shown (Cook and K. Ward, 2011; K. Ward, 2011; González, 2011). For example, the ways in which it disaggregates and reassembles cities, much like other forms of tourism. Here as González (2011) notes, sites (building, parks, roads, waterways etc.) are transformed into sights (objects upon which to gaze and interpret), with hosts repackaging individual components through inter-locking and overarching narratives that attempt to exceed the sum of the parts. Moreover, policy tourism always involves the encountering and discussion of some objects, places, narratives and people, while at the same time silencing, dismissing or leaving out others. Yet for all these similarities, the ways in which through policy tourism is organized, performed, experienced remains contingent and shaped in part by their wider contexts.

Third, the paper seeks to demonstrate the usefulness of archives - personal and institutional - in exploring the geographies and histories of policy tourism. Of course, we do not need to convince the urban historian reading this - they know already! However, a significant proportion of the recent policy mobilities work has rested on semi-structured interviews with involved actors, together with some limited ethnography and participant observation. Yet when researching policy mobilities, archival research can be an invaluable tool, providing "a particular window on the geographies of earlier times" (Roche, 2010: 174), especially times that are no longer possible to explore through 'direct contact' with those involved (Hoggart et al., 2002). Indeed, the archives used in this paper provide a series of insights into what those who participated in the 1957-1958 exchange felt about what they 
were doing. These offer new and complimentary insights into past experiences, performativities and contexts of policy tourism and policy mobilities, against which to consider those in the contemporary era.

\section{Emerging Anglo-Soviet connections: 1917-1957}

In the early years after the 1917 Bolshevik revolution, the drive towards a 'better society' in the Soviet Union and the UK took dramatically different forms. In the Soviet Union, the 'official' vision of the better society was a Communist society with rapid industrialization and urbanization (French, 1995). The Soviet city would be a place where workers could live and work, free from capitalist profiteering. In the UK, meanwhile, the inter-war period was marked by hegemonic visions of a better society that was not only urbanizing but suburbanizing. Fundamentally, though, it remained a capitalist one where the market was seen as best placed to shape the built environment, but moderated by a growing but limited range of social welfare, housing provision, infrastructure and town planning policies from government (S.V. Ward, 2004). While such visions were dominant within their respective states, they were not universally supported. Nor, for some, were they completely incompatible. This can be demonstrated by the emerging interest in the Soviet Union and the UK in how the other was planning and building its towns and cities.

A small number in the emerging planning profession in the UK, in particular, became intrigued by state-orchestrated Soviet planning. Such interest was set against a wider context of fear and fascination with the Soviet Union amongst the British public and in the press (David-Fox, 2012), as well as the prevailing view that the UK should towards the United States and Germany if it required inspiration in town planning (S.V. Ward, 2007; 2010b). 
And while British interest in Soviet planning came later than in several other Western countries, especially Weimar Germany, it was attracted to the boldness, scale and radicalism of it that was intriguing, following Stalin's moves from 1928 to industrialize and collectivize the Soviet economy. For a time, at least, in the late 1920s and early 1930 s, it seemed as if the Soviet Union might be the ideal space in which a new modern way of living could emerge (Mumford, 2000, esp. 37-8, 44-9). In this view, the new Soviet space would represent a pure modernity, shaped strictly on principles of functionality and equality, unsullied by private interest, sentiment, privilege or profit. This hope or, for some, conviction encouraged a few, largely ad hoc, visits to the Soviet Union by British architects and planners from 1931 (a few years later than the first equivalent visitors from other European countries and the United States). There was even a small glimmering of interest within government in 1931-2. Thus Kenneth Dodd, a planner from the Ministry of Health (at the time responsible for town planning), visited the Soviet Union in 1932 to study its planning system in detail (Dodd, 1933: 34-53; Journal of the Town Planning Institute, 1954: 80). Dodd (1933: 34) was impressed by the "greatest state planning scheme the world has ever seen". He acknowledged the repugnance of Communism for many but saw clear lessons from the Soviet Union to help shape the emerging British debates on the need for national scale planning. Conversely, there were few professional trips by Soviet planners to the UK, but one notable trip brought a delegation of 14 members of Moscow District Council to London in September 1936, seeking ways of implementing the previous year's General Plan for the Reconstruction of Moscow (The Times, 1936; Town and Country Planning, 1936).

Much like the current era, several organizations acted as intermediaries, shaping the expertise shared and the journeys made. Instead of consultancies and think tanks of considerable geographical-reach, which are often central institutions within modern-day policy mobilities (Prince, 2012; K. Ward, 2006), these were country-specific organizations. 
On the Soviet side, the state travel agency, Intourist, created in 1929, was a key institution. Likewise, was the Union of Soviet Societies for Friendship and Cultural Relations with Foreign Countries (VOKS), a state agency formed in 1925, responsible for arranging visits to the Soviet Union and disseminating relevant information for external audiences about the Soviet Union. In the UK, meanwhile, the initiative mainly came from outside government. The creation in 1924 of the Society for Cultural Relations between the British Commonwealth and the Soviet Union, usually known as the SCR, was an important moment. Supported by many well-known figures from the arts, sciences, humanities and professions, it was the first of what came to be called the 'friendship organizations' (see S.V. Ward, 2012). Politically its membership was left of centre and, like the other friendship organizations that followed, included many with active Communist sympathies. By the early 1930s several British planners or those interested in city building attended SCR events, sharing experiences of, and views on, the Soviet Union. The SCR also arranged trips to the Soviet Union. Sir Ernest Simon, a prominent Manchester-based politician and SCR member, for instance, led a month-long SCR-arranged research trip that resulted in an important book Moscow in the making (Simon et al., 1937). This became the leading British account of Soviet city planning and government during this period, fostering a largely favourable picture of the Soviet Union's planning achievements. Moscow in the making joined a small but growing volume of literature about the Soviet Union, some published by planning bodies such as the Garden Cities and Town Planning Association (soon to become the Town and Country Planning Association) and the Town Planning Institute.

During the war, British interest in the Soviet Union increased dramatically, particularly so in its reconstruction plans. In 1945, the SCR established an Architecture and Planning section which attracted a relatively small but very influential membership, including planners working on some of the most prominent wartime and early post-war plans in the UK 
(Turner, 1985). They included several senior planners from the new Ministry of Town and Country Planning, and many others working on the seminal plans for the reconstruction of London and Coventry and on some of the New Towns (particularly Stevenage and Peterlee).

Yet the broader sense of wartime common purpose with the Soviet Union gave way to mutual fear, hostility and suspicion after 1948 as wartime allies became Cold War enemies. Increasingly tight restrictions on Soviet visas made visits more difficult than in the 1930s while open admiration of Soviet achievements became increasingly problematic. The British Government grew increasingly suspicious of the political agendas of the SCR and other friendship organizations. Following the death of Stalin in 1953, however, a new opportunity for British-Soviet links seemed to be opening under the new Soviet leader, Nikita Khrushchev. To take advantage of this, the British government sought to lay the basis of a more 'neutral' cultural diplomacy that sidelined the pro-Soviet biases of the friendship organizations. In May 1955 the British Council - since 1934 the official agency promoting Britain's international cultural relations - established a Soviet Relations Committee (UK NA BW 2/520). This unusually political move was led by a former Foreign Office minister, Christopher Mayhew, who was experienced in combating international Communist propaganda (Mayhew, 1998: 48-79). Housing and construction (including some urban planning) matters dominated the earliest technical exchanges overseen by the British Council in July and September 1955 (UK NA HLG 128/1). The thaw in British-Soviet relations was politically endorsed at Cabinet level by Duncan Sandys, the Minister of Housing and Local Government (also responsible for planning), who visited the Soviet Union in May 1956, following Khrushchev's visit to Britain in the previous month. The first technical exchanges that focused exclusively on planning were those of 1957-8 discussed later.

The late 1950s were a key period in British-Soviet relations, with major consequences for the fields of housing and planning (S.V. Ward, 2012). For his part, Khrushchev was 
eager to reduce global tension in order to devote more resources to improving Soviet living conditions. He saw learning from Western achievements in housing and urban planning as a key part of this. On the British side, many admired Soviet technological achievements such as the sputnik satellites (first launched in 1957) and the Tu104 which for part of the 1950s was the world's only operational jet airliner. Yet, like many others, British planners were appalled by the brutal Soviet suppression of moves to a more liberal type of Communism in Hungary in late 1956. This challenged the loyalties even of those with strongest sympathies for the Soviet Union whose thinking was also profoundly destabilized by Khrushchev's denunciation of Stalin in his now famous 'Secret Speech' of 1956 (Taubman, 2004: 270-99). For most remaining pro-Soviet architects and planners in Britain, 1956 marked the end and the SCR's Architecture and Planning section effectively collapsed (SCR, 1957: 3-4). The 1957-58 exchanges thus marked an early stage of a new, less automatically sympathetic British approach to Soviet planning relations. Their larger ideological intent was strikingly different to those of earlier SCR-orchestrated visits.

\section{From Vienna to Glenrothes: Beginning the 1957-8 Exchange}

The International Federation of Housing and Planning's $23^{\text {rd }}$ World Congress took place in Vienna, in late July 1956. In attendance was Vice-President, Frederic J. Osborn, also Chairman of the Town and Country Planning Association (TCPA). Osborn was by then a well-known international planning 'celebrity' (Whittick, 1987). As such, he regularly spoke to, and was approached by, planners and policymakers from other nations. In Vienna, he was

introduced to Mr. A. Koudriavtsev of the USSR State Committee on Construction Affairs and leader of the Soviet delegation to the conference. Osborn and Koudriavtsev began 
formulating an idea for possible exchange visits between those interested in housing and planning in both countries. Osborn, whose TCPA had never visited the Soviet Union on its annual foreign 'study tours', was intrigued. For this key intermediary in the international circulation of planning knowledge, here was an opportunity to learn about the latest elaborations of Soviet planning which, under Stalin, had followed a quite different path from Western Europe (where the TCPA study tours would usually visit). Just as importantly both Western Europe and the Soviet bloc were now finally moving beyond the massive reconstructions that followed widespread wartime destruction. As new possibilities for change were opening, there was also an opportunity to learn about different solutions to common challenges. With this opportunity in mind, a series of formal but affable letters were exchanged in ensuing months, agreeing the exchange and finalising details. In the absence of the various time-compression technologies of the present day, such as e-mails, the time involved in making arrangements was greater, as was the sense of distance. Nevertheless, issues such as dates, broad themes of tours and costs were negotiated over several months, with some, no doubt, 'behind-the-scenes' vetting of arrangements.

On 11 September 1957, six Soviet planners arrived in London for a 19 day tour of the UK. The delegation included the heads of planning, architecture and building construction bodies in Minsk, Kiev, Leningrad and Moscow, an acting director of the Academy of Building and Architecture of the USSR, and was led by Mr. S. I. Kolesnikov, the director of the USSR State Committee on Construction Affairs. The visitors were allocated a Britishbased translator by the Soviet Relations Committee of the British Council.

In consultation with the Soviet Relations Committee and Koudriavtsev (who did not attend the tour), the TCPA devised a tour itinerary that focused primarily on post-war urban reconstruction and the ongoing development of new towns. The tour featured visits to several historic and large towns and cities in England and Scotland - London, Stratford-upon- 
Avon, Oxford, Birmingham, Coventry, Stafford, Liverpool, Manchester, Preston, Edinburgh and Glasgow - and rural areas of the Cotswolds, Loch Lomond and the Highlands. Also featured were the New Towns of Hemel Hempstead, Welwyn Garden City, Glenrothes and East Kilbride, each already well experienced in hosting British and overseas policy tourists (see Figure 1). The delegation met many Ministry of Housing and Local Government officials, mayors, planners, architects, Development Corporation officials and university lecturers, and was guided through countless streets, squares, parks and building sites. The Lancashire Evening Post (1957: 1) noted that the visitors were "draped with cameras" on their visit to Preston. Almost everywhere they visited, they were received by local newpaper reporters and photographers (see, for instance, Figure 2).

*Insert Figures 1 and 2 about here*

\section{Experiencing the Soviet Union}

About eight months later, the British delegation arrived in Moscow. The party comprised Richard Edmonds and Frederic J. Osborn, together with Henry Wells (Chairman of Hemel Hempstead Development Corporation), H. Myles Wright (Lever Professor in University of Liverpool's Department of Civic Design), E.G.S. Elliot (Chief Technical Officer at the Ministry of Housing and Local Government) and Dennis W. Riley (Chief Planning Officer of Staffordshire County Council) (see Figure 3). Like the Soviet delegation the previous year, these were all senior planning figures. They also faithfully reflected the white maledominated nature of British planning at the time. 
*Insert Figure 3 about here*

As Figure 4 shows, the tour began and ended in Moscow, on 14 May 1958 and 5 June 1958, respectively. Following their tour, five delegates returned to London via Prague.

Osborn flew to Warsaw to spend seven days in Poland, visiting planning offices and institutes in Warsaw and Kraków, and the latter's new town of Nowa Huta. He was hosted by Professor W. Ostrowski of the Polish Academy of Sciences, whom he had met in Paris earlier in the year, further demonstrating Osborn's standing in Eastern Europe at the time.

*Insert Figure 4 about here*

We will concentrate on the group's Soviet experience here. In doing this, we echo González's (2011) analysis of modern day policy tourism in Spain by considering not only their 'learning destinations' but also the influences and constraints on their learning, mobilities and inter-personal relations. The destinations visited were all within the 'European' part of the Soviet Union, east of the Urals, visiting in sequence Moscow, Leningrad (now St. Petersburg), Kiev, Sochi, Gagra, Krasnodar, Stalingrad (now Volgograd) and finishing back in Moscow (see Figure 4). The publicly available accounts and letters never mention why the eastern Soviet Union was not visited. However, this was probably because large areas here (hosting nuclear and military facilities) were closed to visitors (see Shaw, 1991). In those places which were visited, the pattern was very similar to that followed in the UK, visiting planning offices, city centres, existing housing stock, construction sites, and places of 'historic interest' and 'natural beauty' (see, for instance, Figure 5). They saw plans for three proposed satellite or 'sputnik' towns surrounding 
Leningrad - Sosnobraya Poniana, Otradnoye and Gorsky (Edmonds, 1958b). A significant amount of time was also spent inspecting plans, models and construction sites for the recently announced Industrialized Housing Programme (IHP).

The IHP had been launched by Khrushchev in July 1957 in a bid to end the nation's chronic housing shortage whereby families frequently occupied just one room in a large flat, sharing a bathroom and kitchen with other families. Solitary family living now became the mantra of Khrushchevian planning, provided quickly and at low cost. The new Soviet housing would comprise five-storey apartment blocks with standardized construction dimensions and materials (McCutcheon, 1989). Millions of such dwellings were built, where, as Varga-Harris (2008: 565) later argued, "form was to follow function", a shift from the extravagant 'wedding cake' style of architecture favoured under Stalin. Kitchens were small and ceilings low. Concrete panels, stairwells, landings and roofs were fabricated in factories and assembled on-site (McCutcheon, 1989; Varga-Harris, 2008; Reid, 2009). The IHP, as Reid (2009: 473) notes, marked "a rapprochement with modernist principles of design dictated by function, materials and mode of production". It was a Soviet variant on modernism, but also one that was directly influenced by similar housing and construction projects in France, Sweden, Denmark and Britain - where Soviet architects visited several factories producing housing components. This take on modernist housing was of great interest to the British delegations as the UK, too, was continuing to build and upgrade housing and, increasingly, flats after the Second World War. Furthermore, modernism had also become the dominant planning and architectural ideology in the UK where variants taken from both Corbusian and Scandinavian approaches were now most influential. Yet despite such commonalities, the IHP later engendered substantial post-tour criticism by the British delegation as we will show. 
*Insert Figure 5 about here*

Among other sites, they also visited collective farms, coastal resort developments in Sochi, the USSR Agricultural and Industrial Exhibition in Moscow, a pre-fabrication housing plant in Leningrad, as well as the Volga Dam under construction. According to Edmonds (1958d: 8), “opportunities were given by our hosts for seeing something of the Russian way of life". This included being able to see inside lived-in accommodation, rather than just seeing from the outside existing housing and new blocks being constructed. Here was a clear appreciation of the limitations of viewing only the 'abstracted space' of maps and models or exterior façades. In Kiev, for instance, they visited the home of an engineer and his family and, stopping briefly at a collective farm in Kozarichi, they saw inside a farm worker's home:

“... a pleasant little wooden dwelling, cool within, spotlessly clean, and unlike any farmhouse I have ever seen. The children - three of them - peered at us from behind the curtain leading to the kitchen, but they came out cheerfully enough to take part in the photographic barrage" (Edmonds, 1958d: 69)

More leisurely trips - or as one 'Planning Commentary' in Town and Country Planning (1958a: 308) called it "VIP entertainment" - included numerous visits to the theatre and circus (seeing the famous clown Popoff) and the Soviet Union-England football match. Participating on the tour, therefore, involved work and leisure. It reflected a belief that the visitors should not only have 'time-off', but also that it was important to experience Soviet popular culture. It also echoed the intermittent use of the label 'study-holiday tours' by the TCPA for its policy tourism during the 1950s. 
Delegates' accounts of the tour spoke of generous hospitality. Edmonds, for instance, reminisces about "repeated [Anglo-Soviet] toasts to planning and to friendship" (1958d: 19) and "the genuine feeling of goodwill behind the whole proceedings" (ibid: 124). Yet accounts also highlight the formality and sense of decorum that accompanied this hospitality. Osborn, for instance, noted that conversations with their hosts "were all on a very high level of serious discussion, mutual respect, and friendliness" (Town and Country Planning, 1958a: 309). Although "propaganda was not entirely absent - there were of course pleas, which on both sides were obviously sincere, for peace and better understanding - but tendentious and controversial international issues never obtruded” (ibid: 309). Echoing prevailing impressions of planning professionals at the time, Osborn (1958a: 8) elsewhere maintained that "our mission, being technical, we did not discuss political issues". It thus seems unlikely that atomic weapons or the recent Suez or Hungary invasions were ever discussed. Osborn (1958b: 393) also admitted that he rarely made criticisms when in conversation with the hosts. His role in these settings was primarily to "inform them about what we do and why, and perhaps late in a convivial evening hazard a criticism about the other party's practice and laugh when it is shot down". There were, it seems, tacit rules of acceptable behaviour on the tour.

Despite these understandings and wider Western representations of the Soviet Union as being secretive and repressive, the reports highlighted the delegates' surprise about their ability to move and take photographs relatively freely (the camera was an important 'mobile' technology of policy tourism, as it is now, albeit in different ways). Discussing the itinerary, Wells (1959: 374), for instance, noted "I did not feel that we were only being allowed to see "what was good for us" although naturally the Russians wanted to show us those things that they were most proud". Edmonds (1958d: 48) offered a more nuanced assessment of their freedom: 


\begin{abstract}
"In the afternoon members of the delegation took the opportunity to wander at will through the city [of Leningrad] unaccompanied and unfettered in every way, and certainly not followed. Both in Moscow and Leningrad this freedom of action has been most apparent, although in a full programme the chances for wandering at will are naturally limited. Photography is also unfettered; but the sensible traveller does not take pictures of bridges and industrial installations. If the point did arise his [sic] guide would probably insist on the visitor's right to take the pictures".
\end{abstract}

So while Riley (1959: 26) suggested that “[t]he magic word 'delegation' seemed to smooth our path wherever we went", the reports do not reveal any behind-the-scenes negotiations and screening that allowed and facilitated such mobility. The biggest obstacles to learning according to the reports however were language and time. With regard to the former, none of the delegates spoke fluent Russian and the group relied heavily on their interpreters. On the latter, although the tour was lengthy (at 22 days) compared to most study tours today and in the 1950s, some of their reports cast doubt on the depth of their learning. They echoed Osborn's (1953: 649) sentiments following a previous TCPA tour to France in 1953 where he did not "cherish the illusion that after one fortnight in a country we come back with a complete picture".

Neither these obstacles nor Osborn's belief (revealed in notes for a Planning Club Rotary Forum talk on 7 July 1958) that "VIP travel could give unbalanced impressions" prevented most of the accounts being very critical of planning and construction in the Soviet Union. Aspects did receive some praise, such as Edmonds' avid approval of the grandiose metro stations in Moscow and Leningrad and the architecture of the Kremlin and pre- 
Revolutionary Leningrad which featured "at every turn... something to catch the photographer's eye" (Edmonds, 1958d: 38). Nonetheless, Soviet post-war reconstruction and the Industrialized Housing Programme in particular (see Figure 6) received stinging criticism in most of the delegates' published reports.

\section{*Insert Figure 6 about here*}

Osborn's comment that (1958a: 8) "[t]he constructional quality and finish of most flats are, by our standards, poor, and much of the architecture and layout dull and monotonous” typified many negative comments on 'workmanship'. Wright (1958: 165) noted that it "ranges from the mediocre to the very bad", while Wells (1959: 379) stated that "the finish is very rough; the plumbing poor. Internal woodwork and painting are generally very rough". Nor were these comments, of course, without merit. As Reid (2009) notes, many Soviet citizens later referred to this housing as khrushcheby, merging 'Khrushchev' and the Russian word for 'slum'.

Floor space, housing numbers, household occupations, wages, rents, industrial output (of housing and other units), among others, were extensively cited in the reports and Osborn's various lecture notes, and quantitatively compared to those in the UK. Many of these statistics, of course, were continually being assessed and espoused by political leaders and the media in the East and West at the time. Combining these statistics with their more qualitative and mainly negative assessments of their site visits created a relational comparative message and a sense of authority that the Soviet Union was lagging (far) behind the UK, with Wright (1958: 177) maintaining that "Russia is going through its Victorian period". While the delegates clearly found the Soviet Union interesting, it was for them a nation that offered 
few, if any, prescriptions for UK urban renewal. Indeed, Wells (1959: 378) bluntly concluded that, "[i]n general, the Russians have nothing to teach us in principles of town planning”.

So while the delegates brought back memories of warm hospitality and encountering new and 'exotic' places, they brought no 'positive lessons' for British planning or, more accurately, models that British planners might want to emulate. Indeed, following the tour reports, the Soviet Union rarely appeared in any of the delegates' subsequent written publications. It was not just that limited time in the Soviet Union, or language barriers, had restricted understanding and therefore their admiration. Nor was it that they could not divorce planning practice or construction work from the Communist political system, as they also believed in the technical, apolitical nature of planning (whether misguided or not). It was mainly that they were simply unimpressed with the technical implementation of Soviet housing and planning projects.

Nevertheless, this tour gave them stories to tell about what Wells (1959: 374) terms "the Russian enigma". This is not something to overlook. They were able to write their accounts in reports, newspapers, a book and present their 'adventures' to audiences from the Women's Institute (Osborn) to a General Meeting of the Town Planning Institute (Riley). They were part of a relatively small number of Westerners who had visited the often maligned but, most importantly, much-talked about Soviet Union. Their attendance could gain reputational capital for themselves, their organizations, and their nation. For Riley (1958: 26), they were the ones who could help unmask the "atmosphere of mystery as to what is really happening behind the Iron Curtain". And in this sense, they differed little from mainstream travel writers, reporting back from unfamiliar, exotic and 'dangerous' territories (Duncan and Gregory, 1999; Thomson, 2011). In addition, the interest Communist Soviet planners had in British planning and its new towns in particular was seen to enhance the 
status of British planning and planners, something that could provide flattering headlines such as "Russians emulate British planning" (Manchester Guardian, 1958) and "Russia tackles her housing jam with British ideas" (Osborn, 1958a). So while positive lessons were not in the returning suitcase, they personally came back with enhanced international reputations.

\section{Conclusion}

As a follow-up the TCPA finally arranged a 'normal' annual study tour to the Soviet Union in 1960, though none of the 1958 delegation returned (Maxwell, 1960). Other planning visits to the Soviet Union arranged by government agencies and other planning interest groups followed intermittently in the 1960s and 1970s (S.V. Ward, 2012). But no later visits generated as much interest as the 1958 or earlier trips. Less and less did British planners think that they might ever draw positive lessons from their Soviet counterparts. With the British legacy of wartime collectivism fading, it was the United States that seemed to entice planners in the UK with a new urbanism based around an affluent, motorized, consumer capitalist society (S.V. Ward, 2007). Furthermore, British interest in Soviet urban and regional development became increasingly academic - a process led by geographers (see Oldfield et al., 2011). Where British planners continued to interact with the Soviet Union, the focus was far more on showcasing British planning rather than on reciprocal learning.

Many of the aspects of policy tourism in the 1950s (and earlier) described here are familiar to those investigating more recent episodes (Cook and Ward, 2011; K. Ward, 2011; González, 2011). Visits were organized through government and professional groups, and were a way for those involved to learn from each other. The choreographing of visits was 
negotiated between officials in both countries and various state and professional sponsored intermediaries. Activities included room-based meetings and tours around cities and neighbourhoods. Conviviality and hospitality clearly suffused these visits, in a way highlighted by some working on contemporary relations between city actors (Jayne et al., 2011). They were not purely transactional. Yet these aspects also highlight profound differences in the wider frameworks within which policy tourism occurred. The larger sense of planning visits forming part of a wider cultural diplomacy intended to reduce the chill of the Cold War is strikingly different from their place today in policy tourism. The consciously pro-Soviet basis of earlier visits orchestrated by the SCR which the British Council-system largely replaced in the 1950s shows yet another approach. Both types had larger and more consciously ideological purposes than the far more focused and in some ways simpleralthough no less political - preoccupations of today's policy tourism.

This paper, we hope, demonstrates the need for scholars of policy mobilities as well as those who have studied the trans-nationalization of planning and architecture to come to together in productive dialogue (Harris and Moore, 2013). It has shown how studies of policy mobilities need to think about path-dependency, evolution and the contexts through, and places in which, policy learning occur. The experience of policy tourism, after all, is shaped not only by the participants and the organisers but also by the geographical and historical contexts in which it takes place. This paper has also made a case for moving away from a preoccupation with the neo-liberal present, important as it is, to decentre - historically and geographically - our understandings of policy tourism and the production of the city. As we have shown, there is a history to the comparison and learning that involves countries beyond Anglo-America. Finally, this paper has demonstrated, drawing on the insights of urban historians and planners, the potential of archival research in offering an insight into 
past experiences, performativities and contexts of policy tourism. Going into the archives can help us better the circulation of policy ideas between cities, near and far, past and present.

\section{References}

Allen, J., Massey, D. and Cochrane, A. (1998) Re-thinking the region. Routledge, London.

Almandoz, A. (1999) Transfer of ideas: the emergence of Venezuelan urbanism in the proposals for 1930s' Caracas. International Planning Studies 4.1, 79-94.

Amin, A. (2004) Regions unbound: towards a new politics of place. Geografiska Annaler Series B: Human Geography 86.1, 33-44.

Banerjee, T. (2009) U.S. planning expeditions to postcolonial India: from ideology to innovation in technical assistance. Journal of the American Planning Association 75.2, 193208.

Bunnell, T. and Maringanti, A. (2010) Practicing urban and regional research beyond metrocentricity. International Journal of Urban and Regional Research 34.2, 415-420.

Clarke, N. (2012) Actually existing comparative urbanism: imitation and cosmopolitanism in north-south interurban partnerships. Urban Geography 33.6, 796-815. 
Cook, I. R. (2008) Mobilising urban policies: the policy transfer of US Business Improvement Districts to England and Wales. Urban Studies 45.4, 773-795.

Cook I. R. and Ward, K. (2011) Trans-urban networks of learning, mega-events and policy tourism: the case of Manchester's Olympic and Commonwealth Games projects. Urban Studies 48.12, 2519-2535.

Cook, I. R. and Ward, K. (2012a) Conferences, informational infrastructures and mobile policies: the process of getting Sweden 'BID ready'. European Urban and Regional Studies, $19.2,137-152$.

Cook, I. R. and Ward, K. (2012b) Relational comparisons: the assembling of Cleveland's waterfront plan. Urban Geography, 33.6, 774-795.

Cooke, C. (1977) Activities of the Garden City Movement in Russia. Transactions of the Martin Centre for Architectural and Urban Studies, 1, 225-49.

Cooke, C. (1978) Responses to the garden city idea, Architectural Review, 163, 354-63.

David-Fox, M. (2012) Showcasing the great experiment: cultural diplomacy and Western visitors to the Soviet Union, 1921-1941, New York: Oxford University Press. 
Dodd, K. S. (1933) Planning in the USSR. Journal of the Town Planning Institute 20.1, $34-$ 53.

Dolowitz, D., Greenwold, S. and Marsh, D. (1999) Policy transfer: something old, something new, something borrowed, but why red, white and blue? Parliamentary Affairs 52.4, 719730.

Duncan, J. and Gregory, D. (1999) Writes of passage: reading travel writing. London: Routledge.

Edmonds, R. (1958a) The show place of Moscow - Neighbourhood '9'. The Evening News, 12 June, 6 .

Edmonds, R. (1958b) Sputnik towns. The Evening News, 13 June, 4.

Edmonds, R. (1958c) Sochi... with a touch of Butlin. The Evening News, 14 June, 4.

Edmonds, R. (1958d) Russian vistas: a springtime journey to Moscow, Leningrad, Kiew, Stalingrad, the Black Sea and the Caucasus Phene Press, London. 
Flierl, T. (2011) 'Possibly the greatest task an architect ever faced' - Ernst May in the Soviet Union (1930-1933). In Quiring, C., Voigt, W., Schmal, P. C. and Herrel, E. (eds.), Ernst May 1886-1970. Munich: Prestel, 157-195.

French, R. A. (1995) Plans, pragmatism and people: The legacy of Soviet planning for Today's cities. Pittsburgh: University of Pittsburgh Press.

Friedman, A. (2012) The global postcolonial moment and the American New Town: India, Reston, Dodoma. Journal of Urban History 38.3, 553-576.

Glasgow Herald, The (1957) Russian town planners at East Kilbride. The Glasgow Herald, 26 September 1957, 10.

Glendinning, M. (2009), Cold-War conciliation: international architectural congresses in the late 1950s and early 1960s. Journal of Architecture, 14.2, 197-217.

González, S. (2011) Bilbao and Barcelona 'in motion': how urban regeneration 'models' travel and mutate in the global flows of policy tourism. Urban Studies 48.7, 1397-1418.

Harris, A. and Moore, S. (2013) Planning histories and practices of circulating urban knowledge. International Journal of Urban and Regional Research (forthcoming). 
Healey, P. (2010) Introduction: the transnational flow of knowledge and expertise in the planning field. In Healey, P. and Upton, R. (eds.) Crossing borders: international exchange and planning practices. Routledge, London, 1-26.

Healey, P. and Upton, R. (2010) (eds.) Crossing borders: international exchange and planning practices. Routledge, London.

Hoggart, K., Lees, L. and Davies, A. (2002) Researching human geography. London: Arnold. Jacobs, J. (2012) Urban geographies I: still thinking relationally. Progress in Human Geography 36.3, 412-422.

Jacobs, J. and Lees, L. (2013) Defensible space on the move: revisiting the urban geography of Alice Coleman. International Journal of Urban and Regional Research (forthcoming).

Jayne, M., Hubbard, P. and Bell, D. (2011) Worlding a city: twinning and urban theory. City 15.1: $25-41$.

Journal of the Town Planning Institute (1954) Notice. Journal of the Town Planning Institute, 40,80 . 
King, A. (1980) Exporting planning: the colonial and neo-colonial experience. In Cherry, G. (ed.) Shaping an urban world. New York: St. Martin's Press, 203-226.

Kentish Mercury (1958) Going behind the curtain. Kentish Mercury, 9 May 1958, 5.

Kopp, A. (1990) Foreign architects in the Soviet Union during the first two five-year plans. In Brumfield, W. C. (ed.) Reshaping Russian architecture: Western technology, utopian dreams. New York: Cambridge University Press, 176-214.

Lancashire Evening Post (1957) Six solemn Russians visit Preston. Lancashire Evening Post, 20 September $1957,1$.

Manchester Guardian, (1957) Russians here to see new towns. The Manchester Guardian, 11 September 1957, 4.

Massey, D. (2004) Geographies of responsibility. Geografiska Annaler Series B: Human Geography 86.1, 5-18.

Massey, D. (2007) World city. Polity Press, Cambridge.

Maxwell, R. I. (1960) Town planning tour of the USSR. Town and Country Planning 28.9, $320-328$. 
Mayhew, C. (1998) A war of words: a Cold War witness. Tauris, London.

McCann, E. J. (2004) 'Best places': interurban competition, quality of life and popular media discourse. Urban Studies 41.10, 1909-1929.

McCann, E. J. (2008) Expertise, truth, and urban policy mobilities: global circuits of knowledge in the development of Vancouver, Canada's 'four pillar' drug strategy. Environment and Planning A 40.4, 885-904.

McCann, E. J. (2011) Urban policy mobilities and global circuits of knowledge: toward a research agenda. Annals of the Association of American Geographers 101.1, 107-130.

McCann, E. J. and Ward, K. (2011) (eds.) Mobile urbanism: cities and policy-making in the global age. Minnesota: University of Minnesota Press.

McCann, E. J. and Ward, K. (2012a) Assembling urbanism: following policies and 'studying through' the sites and situations of policy making. Environment and Planning A 44.1, 42-51.

McCann, E. J. and Ward, K. (2012b) Policy assemblages, mobilities and mutations: toward a multidisciplinary conversation. Political Studies Review 10.3, 325-332. 
McCutcheon, R. (1989) The role of industrialised building in Soviet Union housing policies. Habitat International 13.4, 43-61.

McFarlane, C. (2010) The comparative city: knowledge, learning, urbanism. International Journal of Urban and Regional Research 34.4, 725-742

Meller, H. (1995) Philanthropy and public enterprise: international exhibitions and the modern town planning movement, 1889-1913. Planning Perspectives, 10.3, 295-310.

Mumford, E. (2000) The CIAM discourse on urbanism, 1928-1940, Cambridge MA: MIT Press.

Oldfield, J. Matless, D. and Swain, A. (2011) The making of a sub-discipline: state initiatives and the production of British geographical studies of the Soviet Union and Eastern Europe, 1945-71. Transactions of the Institute of British Geographers, 36.4, 574-89

Osborn, F. J. (1953) Planning and housing in France: 1. Town and Country Planning 21.10, $648-653$

Osborn, F. J. (1958a) Russia tackles her housing jam with British ideas. The Daily Telegraph and Morning Post, 15 July, 8. 
Osborn, F. J. (1958b) Soviet city development in 1958. Town and Country Planning 26.10, $385-393$.

Peck, J. (2002) Economies of scale: fast policy, interscalar relations, and neoliberal workfare. Economic Geography 78.3, 331-360.

Peck, J. (2011) Recreative city: Amsterdam, vehicular ideas and the adaptive spaces of creativity policy. International Journal of Urban and Regional Research 36.3, 462-485.

Peck, J. and Theodore, N. (2001) Exporting workfare/importing welfare-to-work: exploring the politics of third way policy transfer. Political Geography 20.4, 427-460.

Peck, J. and Theodore, N. (2010a) Mobilizing policy: models, methods, and mutations. Geoforum 41.2, 169-174.

Peck, J. and Theodore, N. (2010b) Recombinant workfare, across the Americas: transnationalizing "fast” social policy. Geoforum 41.2, 195-208.

Phelps, N. and Tewdwr-Jones, M. (2008) If geography is anything, maybe it's planning's alter ego? Reflections on two disciplines concerned with policy relevance concerned with place and space. Transactions of the Institute of British Geographers 33.4 566-584. 
Prince, R. (2010) Policy transfer as policy assemblage: making policy for the creative industries in New Zealand. Environment and Planning A 42.1, 169-186.

Prince, R. (2012) Policy transfer, consultants and the geographies of governance. Progress in Human Geography 36.2, 186-203.

Reid, S. E. (2009) Communist comfort: socialist modernism and the making of cosy homes in the Khrushchev era. Gender and History 21.3, 465-498.

Riley, D. W. (1959) Land use planning in Soviet Russia. Journal of the Town Planning Institute 45.2, 26-32.

Robinson, J. (2004) In the tracks of comparative urbanism: difference, urban modernity and the primitive. Urban Geography 25.8, 709-723.

Robinson, J. (2011) Cities in a world of cities: the comparative gesture. International Journal of Urban and Regional Research 35.1, 1-23.

Roche, M. (2010) Historical research and archival sources. In Hay, I. (ed.) Qualitative research methods in human geography. Third edition. Oxford: Oxford University Press, 173190. 
Sanyal, B. (1990) A new turn of events: knowledge transfer from poor to rich cities. Cities 7.1, 31-36.

SCR (Society for Cultural Relations between the British Commonwealth and the Soviet Union) (1957) $32^{\text {nd }}$ annual report 1956-7. SCR, London.

Shaw, D.J.B. (1991) Russia. In Hall, D. R. (ed.) Tourism and economic development in Eastern Europe and the Soviet Union. Belhaven, London.

Simon, E. D., Simon, S., Robson, W. A. and Jewkes, J. (1937) Moscow in the making. Longmans Green, London.

Stead, D., de Jong, M. and Reinholde, I. (2010) West-East policy transfer in Europe: the case of urban transport policy. In Healey, P. and Upton, R. (2010) (eds.) Crossing borders: international exchange and planning practices. Routledge, London, 173-190.

Stanek, L. and Avermaete, T. (eds.) , (2012) Cold War transfer. Architecture and planning from socialist Countries in the "third world", Journal of Architecture (special issue), 17.

Sutcliffe, A. (1981) Towards the planned city: Germany, Britain, the United States and France 1780-1914. Basil Blackwell, Oxford. 
Taubman, W. (2004) Khrushchev: the man and his era. Free Press, London.

Temenos, C. and McCann, E. (2012) The local politics of policy mobility: learning, persuasion, and the production of a municipal sustainability fix. Environment and Planning $A$ 44.6, 1389-1406.

Thompson, C. (2011) Travel writing. London: Routledge.

Times, The (1936) Russians' study of English methods. The Times, 12 September 1936.

Town and Country Planning (1936) Russian visitors. Town and Country Planning 5.1, 24.

Town and Country Planning (1958a) Our planners in the USSR. Town and Country Planning $26.8,308-309$.

Town and Country Planning (1958b) The USSR through several glasses. Town and Country Planning 26.12, 470-472.

Town and Country Planning (1958c) Photograph. Town and Country Planning 26.12, 480.

Town Planning Review (1958) Editorial notes, Town Planning Review 29.2, 75-78. 
Turner, J. (1985) SCR Architects and Planners Group 1945-56. Anglo-Soviet Journal 45, 3-7.

UK NA BW 2/520 (UK National Archives) Soviet Relations Committee: correspondence about its formation in 1955 and its responsibilities.

UK NA HLG 128/1. Minister's visit to Russia.

Varga-Harris, C. (2008) Homemaking and the aesthetic and moral perimeters of the Soviet home during the Khrushchev era. Journal of Social History 41.3, 561-589.

Ward, K. (2006) 'Policies in motion', urban management and state restructuring: the translocal expansion of Business Improvement Districts. International Journal of Urban and Regional Research 30.1, 54-75.

Ward, K. (2010) Towards a relational comparative approach to the study of cities. Progress in Human Geography 34.4, 471-487.

Ward, S.V. (2004), Planning and urban change, $2^{\text {nd }}$ ed., London, Sage.

Ward, S. V. (2007) Cross-national learning in the formation of British planning policies 1940-99: a comparison of the Barlow, Buchanan and Rogers Reports. Town Planning Review, 78.3, 369-400. 
Ward, S. V. (2010a) Transnational planners in a postcolonial world. In Healey, P. and Upton, R. (eds.) Crossing borders: international exchange and planning practices. Routledge, London, pp. 47-72.

Ward, S. V. (2010b) What did the Germans ever do for us? A century of British learning about and imagining modern planning. Planning Perspectives 25.2, 117-40.

Ward, S. V. (2012) Soviet communism and the British planning movement: rational learning or Utopian imagining? Planning Perspectives 27.4, 499-524.

Wells, H. W. (1959) A chartered surveyor looks at Soviet Russia. The Chartered Surveyor $91.7,374-381$.

Whittick, A. (1987) F.J.O. - practical idealist: a biography of Sir Frederic J. Osborn. Town and Country Planning Association, London.

Wright, H. M. (1958) A visit to Russia. Town Planning Review 29.3, 163-178. 